\title{
Corona-Like Illness: Did we get it before WHO Announcement of the Disease? A Cross-sectional Survey
}

\author{
Aliae AR Mohamed-Hussein ${ }^{1 \star}$, Nahed A Makhlouf ${ }^{2}$, Heba Yassa ${ }^{3}$, Hoda A Makhlouf ${ }^{1}$
}

\author{
${ }^{1}$ Professor, Department of Chest Diseases, Faculty of Medicine, Assiut University, Assiut, EGYPT \\ ${ }^{2}$ Professor, Department of Tropical Medicine and Gastroenterology, Faculty of Medicine, Assiut University, Assiut, EGYPT \\ ${ }^{2}$ Professor, Department of Forensic Medicine and Clinical Toxicology, Faculty of Medicine, Assiut University, Assiut, EGYPT \\ *Corresponding Author: aliaehussein@aun.edu.eg
}

Citation: Mohamed-Hussein AAR, Makhlouf NA, Yassa H, Makhlouf HA. Corona-Like Illness: Did we get it before WHO Announcement of the Disease? A Cross-sectional Survey. Electron J Gen Med. 2020;17(6):em258. https://doi.org/10.29333/ejgm/8373

ARTICLE INFO
Received: 6 May 2020
Accepted: 14 Jun. 2020

\begin{abstract}
Background: In Wuhan, cases with pneumonia of unknown etiology were reported in December 2019 and Coronavirus, called SARS-CoV-2 was detected in the lower respiratory tract samples of these patients. WHO has declared the infection a Pandemic on March 11, 2020. The most common symptoms of COVID-19 were fever, dry cough, fatigue, and dyspnea, myalgia.
\end{abstract}

The aim of the study: To determine the frequency of people who assume they got, "Corona-like illness" before WHO announcement of the disease. Describe their demography and character of the disease.

Material and Methods: This cross-sectional web- based anonymous survey study included participants who were fulfilling online designed questionnaire.

Results: Most of the individuals that fill the questionnaire were in the age group (31-40 years old), most of them were from Egypt $91.5 \%, 10.7 \%$ were smokers, $6.7 \%$ of them with cardiac - hypertension and myocardial ischemia, $47.9 \%$ of them with allergic rhinitis and $23.4 \%$ with asthma. In total, $55.2 \%$ of those who fill the questionnaire have the experience of symptoms like coronavirus symptoms in October, November and early December. About $25.9 \%$ need to be admitted to ER.

Conclusion: Many people may have experienced the disease before the announcement of WHO, especially that the new virus spreads as easily as "Flu". This may explain the spread of the disease among the families as it is very difficult to stop influenza transmission. The antibodies testing would allow us to check blood samples for antibodies against coronavirus to tell whether remote immunity is found in the population or not.

Keywords: corona virus disease, COVID-19, WHO, pandemic

\section{INTRODUCTION}

To date, six CoVs have been known to cause human infection (1). Among them, two zoonotic viruses, SARS-CoV and MERS-CoV, were responsible for serious outbreaks: in China in 2002-2003 (2-3) and in the Middle East in 2012 (4), respectively. A novel coronavirus was identified in late 2019 in Wuhan, China (5). This is a new coronavirus that has not been previously identified in humans. On 11 February, The International Committee on Taxonomy of Viruses (ICTV) announced that the official classification of the new coronavirus (2019-nCoV) is called severe acute respiratory syndrome coronavirus 2 (SARSCoV-2). The World Health Organization (WHO) announced on the same day that the official name of the disease caused by the virus is Corona Virus Disease-19 (COVID-19). WHO has declared the infection a Pandemic on March 11, 2020 (6).

Most of COVID-19 infections are self- limiting. However, COVID-19 causes severe illness in patients with underlying comorbidities and elderly population where mild illness was demonstrated in $81 \%$ patients (7). The most common symptoms of COVID-19 were fever in $88 \%$, dry cough in $67 \%$, fatigue in $38 \%$, dyspnea in $18.7 \%$ and myalgia $14.9 \%$. Other features include sore throat, headache, rhinorrhea and gastrointestinal symptoms (8). More than 1.5 million cases of COVID-19 were confirmed with 92,798 deaths on April 10, 2020 (9).

\section{Rational}

Since there were several reports on cases suffering from " Corona-like illness disease" on October, November and early December, we are wondering is there a chance that this "Corona-like illness" we got it before the WHO announcement of the disease?

\section{The Aim of the Study}

To determine the frequency of people who assume they got, Corona-like illness before WHO announcement of the disease (fever, cough, dyspnea). Describe their demography (gender, age) and character of the disease (mild, moderate or severe requiring ER or ICU admission). 
Table 1. Distribution and demographic variables in the study group $(\mathrm{n}=2921)$

\begin{tabular}{|c|c|c|c|}
\hline Variable & Responders & Frequency & Percentage \\
\hline Gender, male/ female & 2921 & $698 / 2223$ & $23.9 / 76.1$ \\
\hline Age group, years old & 2921 & - & - \\
\hline $20-30$ & & 1046 & 35.8 \\
\hline $31-40$ & & 1339 & 45.8 \\
\hline $41-50$ & & 316 & 10.8 \\
\hline $51-60$ & & 220 & 7.5 \\
\hline Residence & 2919 & - & - \\
\hline Egypt & & 2672 & 91.5 \\
\hline KSA & & 130 & 4.5 \\
\hline UAE & & 48 & 1.6 \\
\hline Middle east & & 28 & 0.9 \\
\hline United Kingdom & & 8 & 0.3 \\
\hline United states of America & & 8 & 0.3 \\
\hline Australia, South Africa & & 25 & 0.9 \\
\hline Special habits* & 2921 & - & - \\
\hline Yes/No & & $503 / 2418$ & $17.2 / 82.8$ \\
\hline Smoker (Cigarettes, Goza) & & 313 & 10.7 \\
\hline Ex-Smokers (cigarettes, Goza) & & 159 & 5.4 \\
\hline Alcohol & & 18 & 0.6 \\
\hline Substance use & & 13 & 0.4 \\
\hline Co morbidities* ${ }^{\star}$ & 2921 & - & - \\
\hline Yes/no & & $560 / 2361$ & $19.2 / 80.8$ \\
\hline Diabetes & & 105 & 3.6 \\
\hline Chronic liver diseases & & 9 & 0.3 \\
\hline $\begin{array}{l}\text { Cardiac- hypertension, } \\
\text { myocardial ischemia }\end{array}$ & & 196 & 6.7 \\
\hline Renal impairment- failure & & 29 & 1 \\
\hline Endocrinal disease & & 76 & 2.6 \\
\hline Malignancy & & 14 & 0.5 \\
\hline Others & & 131 & 4.5 \\
\hline Chronic respiratory diseases ${ }^{\star}$ & 2921 & - & - \\
\hline Yes/no & & $429 / 2492$ & $14.7 / 85.3$ \\
\hline Asthma & & 683 & 23.4 \\
\hline COPD & & 175 & 5.9 \\
\hline Allergic rhinitis & & 1399 & 47.9 \\
\hline Chronic sinusitis & & 1343 & 46 \\
\hline
\end{tabular}

\section{SUBJECTS AND METHODS}

\section{Design}

This cross-sectional web- based anonymous survey study included participants who were fulfilling online designed questionnaire.

\section{Sampling}

Sufficient sample was collected over 2 weeks $(>2000$ response to have response rate $>76 \%$ ). Participants completed the online questionnaire.

\section{Measures}

We designed and validated the questionnaire used in this study. Google forms were used for developing the online questionnaire. The questionnaire had three parts: demographic data, comorbidities and corona like symptoms.

\section{Ethics}

The participation was optional, and the response of each individual was confidential. A statement declaring approval of participation was included at the beginning of the survey. The study is registered in clinicalTrial.gov ID: NCT04336657.

\section{Statistical Analyses}

Google form was used to collect the data. Statistical analysis was performed using SPSS version 22.0 (IBM Corporation, Armonk, NY, USA). Data will be presented number
Table 2. Responses of participants to travel and contact history before October, November, December 2019 ( $n=2921$ )

\begin{tabular}{|c|c|c|c|}
\hline Question & Responders & Frequency & Percentage \\
\hline $\begin{array}{l}\text { Have you traveled to an area with a } \\
\text { known local spread of COVID-19 before } \\
\text { December 2019? }\end{array}$ & 2921 & - & - \\
\hline Yes & & 327 & 11.2 \\
\hline No & & 2594 & 88.8 \\
\hline $\begin{array}{l}\text { Have you come into close contact } \\
\text { (within } 6 \text { feet- } 1.5 \text { meters) with } \\
\text { someone who has Corona like illness in } \\
\text { October- November- early December }\end{array}$ & 2921 & - & - \\
\hline $2019 ?$ & & & \\
\hline Yes & & 429 & 14.7 \\
\hline No & & 1285 & 44 \\
\hline Maybe & & 1207 & 41.3 \\
\hline $\begin{array}{l}\text { Are you a first responder, healthcare } \\
\text { worker, or employee or attendee of a } \\
\text { child or adult care facility? }\end{array}$ & 2920 & - & - \\
\hline Yes & & 1544 & 52.9 \\
\hline No & & 1376 & 47.1 \\
\hline
\end{tabular}

and percentage $(\%)$ or mean \pm SD for continuous variables and percentage for categorical variables.

\section{RESULTS}

Table 1 shows the distribution and demographic variables in the study group. A total of 2921 participants fulfilled online designed questionnaire (Response rate 97.3\% - 2921/3000). However, not all participants responded to all questions. $76.1 \%$ of the responders were females. Age ranged between 20 to 60 years old. More than $45 \%$ of the responders were in their third to fourth decade of life. Most of the responders (82.8\%) had no special habits (smoking, alcohol or drug abuse). Co morbidities were found in $19.2 \%$ of responders. The most common Comorbid disease was Cardiac- hypertension, myocardial ischemia (6.7\%). Chronic respiratory diseases were found in $14.7 \%$ of responders.

Table 2 displays the responses of participants to travel and contact history, where 2921 participants responded to these questions. Only $11.2 \%$ of them traveled to an area with a known local spread of COVID-19 before December 2019. About 14.7\% had close contact with someone who has Corona like illness; however, $44 \%$ had no contact with suspected cases. Regarding work, 52.9\% were healthcare workers, employee or attendee of a child or adult care facility.

Table 3 demonstrates responses of participants regarding suspected "Corona like illness data" in October, November and early December 2019.

About $55.2 \%$ of the responders reported Corona-Like illness in October- November- Early December 2019. 58.3\% of those who had Corona-Like illness reported their illness to be much worse than their usual Flu. More than one third of cases had their Corona like illness persist for 3-5 days and other third had duration of 6-10 days. Subjects with suspected Corona like illness ( $n=1612$ ), reported that $74.1 \%$ did not need Emergency Room (ER) admission or close medical supervision.

Figure 1 shows the phylogenetic network of 160 SARS-CoV2 genomes. Node $A$ is the root cluster obtained with the bat ( $R$. affinis) coronavirus isolate BatCoVRaTG13 from Yunnan Province. Circle areas are proportional to the number of taxa, and each notch on the links represents a mutated nucleotide position. The sequence range under consideration is 56 to 29,797 , with nucleotide position ( $\mathrm{np}$ ) numbering according to 
Table 3. Responses of participants regarding suspected "Corona like illness data" in October, November and early December 2019

\begin{tabular}{|c|c|c|c|}
\hline Question & Responders & Frequency & Percentage \\
\hline $\begin{array}{l}\text { Did you have a fever (greater than } 38.0 \\
\text { C) or symptoms of lower respiratory } \\
\text { illness such as cough, shortness of } \\
\text { breath, difficulty breathing or sore } \\
\text { throat in October- November- Early } \\
\text { December 2019? }\end{array}$ & 2920 & - & - \\
\hline Yes & & 1612 & 55.2 \\
\hline No & & 911 & 31.2 \\
\hline May be & & 397 & 13.6 \\
\hline $\begin{array}{l}\text { IF YES-Do you describe your previous } \\
\text { condition as maybe Corona-Like illness } \\
\text { (much worse than your usual Flu) in } \\
\text { October- November-Early December } \\
2019 ?\end{array}$ & 1612 & - & - \\
\hline Yes & & 939 & 58.3 \\
\hline No & & 420 & 26.1 \\
\hline Maybe & & 251 & 15.6 \\
\hline $\begin{array}{l}\text { IF YES-How many days did you had } \\
\text { what you described as maybe Corona- } \\
\text { Like illness (much worse than your } \\
\text { usual Flu) in October- November- Early } \\
\text { December 2019? }\end{array}$ & 1612 & - & - \\
\hline 3-5 days & & 525 & 32.6 \\
\hline $6-10$ & & 554 & 34.4 \\
\hline $11-15$ & & 290 & 18 \\
\hline$>15$ & & 243 & 15 \\
\hline $\begin{array}{l}\text { If YES-Did you need ER admission or } \\
\text { close medical supervision for your } \\
\text { "Corona like illness" }\end{array}$ & 1612 & - & - \\
\hline Yes & & 418 & 25.9 \\
\hline No & & 1194 & 74.1 \\
\hline
\end{tabular}

the Wuhan 1 reference sequence (8). The median-joining network algorithm (2) and the Steiner algorithm (9) were used, both implemented in the software package Network5011CS (https://www.fluxus-engineering.com/), with the parameter epsilon set to zero, generating this network containing 288 most-parsimonious trees of length 229 mutations. The reticulations are mainly caused by recurrent mutations at np11083. The 161 taxa (160 human viruses and one bat virus) yield 101 distinct genomic sequences. The phylogenetic diagram is available for detailed scrutiny in A0 poster format and in the free Network download files (14).

Figure 2 shows HRCT pulmonary windows of 27years old female patients on 18 December 2019, with fever, cough, and dyspnea for 2 weeks showing nodules of ground glass appearance with reverse halo appearance with the HRCT report.

\section{DISCUSSION}

Coronavirus pandemic is a pandemic caused by severe acute respiratory syndrome coronavirus 2 (SARS- CoV 2), was identified in Wuhan, China in December 2019 (10). The WHO proved that the outbreak to be an international emergency on $30^{\text {th }}$ January 2020 and prove that it is a pandemic on the 1 st of March 2020 (11). The hypothesis of this paper was that, were people take the infection before the announcement of the WHO or not?

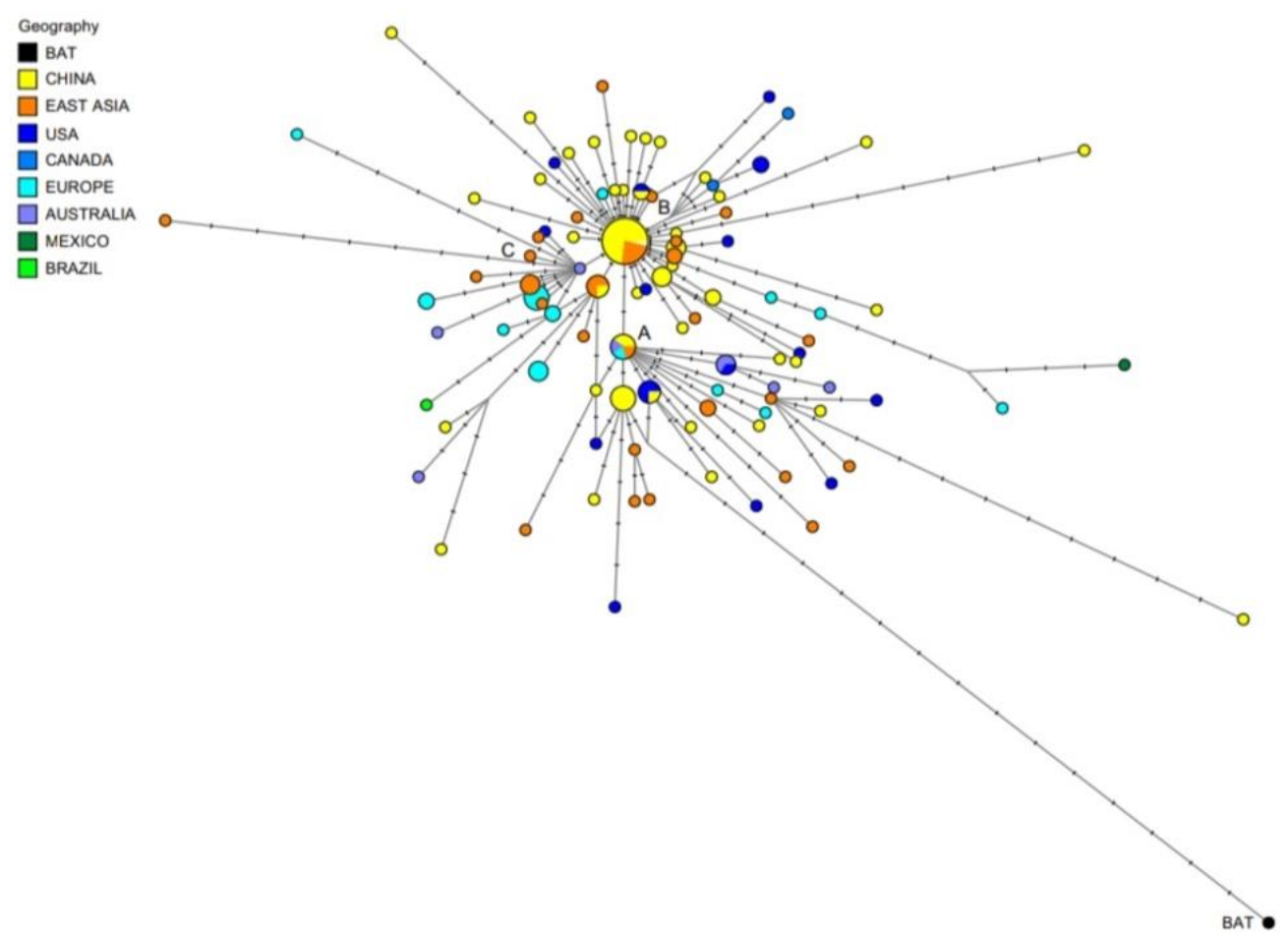

Figure 1. Phylogenetic network of 160 SARS-CoV-2 genomes. Node A is the root cluster obtained with the bat ( $R$. affinis) coronavirus isolate BatCoVRaTG13 from Yunnan Province. Circle areas are proportional to the number of taxa, and each notch on the links represents a mutated nucleotide position. The sequence range under consideration is 56 to 29,797, with nucleotide position (np) numbering according to the Wuhan 1 reference sequence (8). The median-joining network algorithm (2) and the Steiner algorithm (9) were used, both implemented in the software package Network5011CS (https://www.fluxus-engineering.com/), with the parameter epsilon set to zero, generating this network containing 288 most-parsimonious trees of length 229 mutations. The reticulations are mainly caused by recurrent mutations at np11083. The 161 taxa (160 human viruses and one bat virus) yield 101 distinct genomic sequences. The phylogenetic diagram is available for detailed scrutiny in A0 poster format and in the free Network download files. 

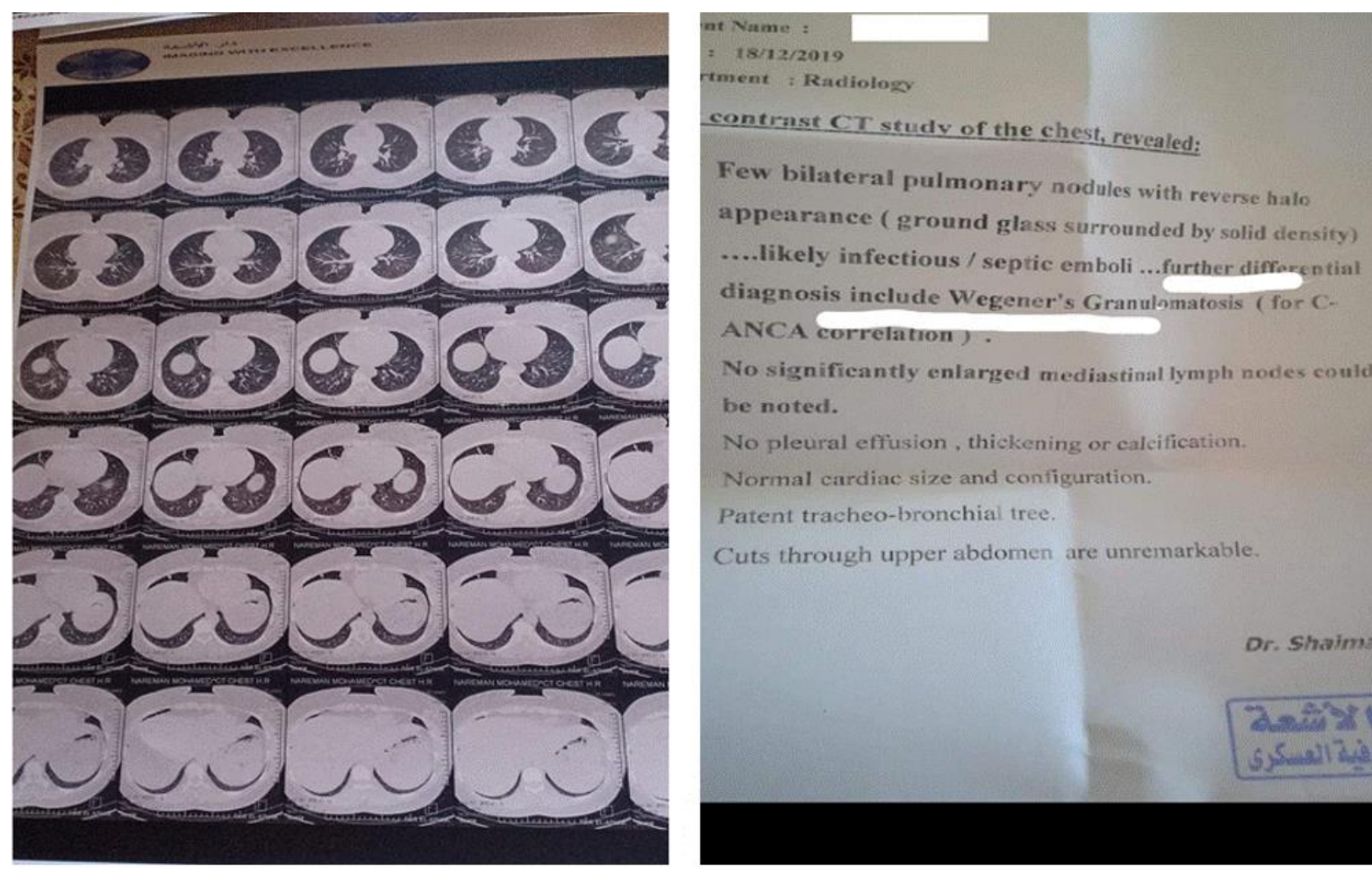

Figure 2. HRCT of 27 years old female patient with fever, cough, dyspnea on 18/12/2019 showing ground glass opacity with reversed halo sign

Most of the individuals who fill the questionnaire were in the age group (31-40 years old), $10.7 \%$ were smokers, $6.7 \%$ of them with cardiac - hypertension and myocardial ischemia, $47.9 \%$ of them with allergic rhinitis and $23.4 \%$ with asthma. A total of $55.2 \%$ of those who fill the questionnaire had the experience of symptoms like coronavirus symptoms in October, November and early December. About 25.9\% needed to be admitted to ER.

The finding of this report maybe logic as according to Robert Redfield, the director of the centers for disease Control and Prevention, $25 \%$ of people can be infected with the COVID 19 with no symptoms or mild one without falling ill but can still transmit the disease to others (12). Hong Kong team suggests that from $20-40 \%$ of transmission in China occurred before appearance of symptoms (13).

Moreover, a recent report published few days ago suggests "the coronavirus outbreak could have started as early as midSeptember, and the Chinese City Wuhan may not be where it began (14). They used the GISAID database (https://www.gisaid.org/) contained a compilation of 253 severe acute respiratory syndrome coronavirus 2 (SARS-CoV-2) complete and partial genomes presented from across the world since December 2019. They presented a phylogenic network of 160 largely complete SARS-CoV-2 genome to assess the evolution and track the infection pathways (Figure 1). Using Monte Carlo simulations, Wells and colleagues estimated that about $64 \%$ of exported cases were in presymptomatic incubation period upon arrival to any Airport, indicating that even screening in Airports was unlikely to prevent disease importation (15).

The "corona-like illness" did not attract any attention in early October, November, December especially in Middle East countries back then as severe pneumonia cases were not recorded and the illness was described as " worse than their usual Flu" as recorded in the present study. This may be explained by the speculation that those with higher levels of ACE-2 receptors may be at greater risk of severe disease and the expression of ACE-2 receptors may be linked to race (16). Early reports suggested that Asian males had higher ACE-2expressing cell ratios compared to white and African Americans (17).

\section{CONCLUSION}

We concluded that many people may have experienced the disease before the announcement of WHO, especially that the new virus spreads as easily as "Flu". This may explain the spread of the disease among the families as it is very difficult to stop influenza transmission. Also, this may explain the pandemic pattern affecting different areas throughout the globe as cases were not defined or diagnosed. The antibodies testing would allow us to check blood samples for antibodies against coronavirus to tell whether remote immunity is found in the population or not. Further analysis of cases of unexplained pneumonias in last year is needed.

\section{RECOMMENDATIONS}

We recommend doing IgM/IgG serological assay especially to the communities as well as to healthcare providers for the diagnosis of SARS-CoV-2 recent and remote infections. This will assess the overall immune response to the virus. This step may permit a gradual cease of lockdown all over the world to decrease the economic burden of the pandemic. However, the infection control measures and the travel, border control measure should be followed carefully to avoid a "second wave" of the disease. 


\section{REFERENCES}

1. Su S, Wong G, Shi W, et al. Epidemiology, genetic recombination, and pathogenesis of coronaviruses. Trends Microbiol. 2016;24:490-502. https://doi.org/10.1016/j. tim. 2016.03.003 PMID:27012512 PMCID:PMC7125511

2. Normile D. Infectious diseases. Battling SARS on the frontlines. Science. 2003;300:714-5. https://doi.org/ 10.1126/science.300.5620.714 PMid:12730562

3. Zhong NS, Zheng BJ, Li YM, et al. Epidemiology and cause of severe acute respiratory syndrome (SARS) in Guangdong, People's Republic of China, in February, 2003. Lancet. 2003;362:1353-8. https://do.i.org/10.1016/s01406736(03)14630-2

4. Zaki AM, Van Boheemen S, Bestebroer TM, et al. Isolation of a novel coronavirus from a man with pneumonia in Saudi Arabia. N Engl J Med. 2012;367:1814-20. https://doi.org/ 10.1056/NEJMoa1211721 PMid:23075143

5. World Health Organization. Pneumonia of Unknown Cause - China. Available at: https://www.who.int/csr/don/05january-2020-pneumonia-of-unkown-cause-china/en/ (Accessed: 14 February 2020).

6. World Health Organization (WHO) WHO Director-General's opening remarks at the media briefing on COVID-19 - 11 March 2020. 2020. Available at: https://www.who.int/dg/ speeches/detail/who-director-general-s-opening-remarks -at-the-media-briefing-on-covid-19---11-march-2020

7. Wu Z, McGoogan JM. Characteristics of and Important Lessons from the Coronavirus Disease 2019 (COVID-19) Outbreak in China: Summary of a Report of 72314 Cases from the Chinese Center for Disease Control and Prevention. JAMA 2020;323(13):1239-42. https://doi.org/ 10.1001/jama.2020.2648 PMid:32091533

8. Guan WJ, Ni ZY, Hu Y, Liang WH, Ou CQ, He JX, Liu L, Shan $\mathrm{H}$, Lei CL, Hui $\mathrm{D}$, et al. Clinical characteristics of coronavirus disease 2019 in China. N Engl J Med. 2020;382:1708-20. https://doi.org/10.1056/NEJMoa2002032 PMid:32109013 PMCid:PMC7092819
9. World Health Organization (WHO) 2020. Situation report 81 Coronavirus disease 2019 (COVID-19). 10 April 2020. Available at: https://www.who.int/emergencies/diseases/ novel-coronavirus-2019/situation-reports

10. World Health Organization (WHO) WHO Novel Coronavirus - China. 12 January 2020. Available at: https://www.who.int/csr/don/12-january-2020-novelcoronavirus-china/en/ (Accessed: 18 April 2020).

11. Statement on the second meeting of the International Health Regulations. Emergency Committee regarding the outbreak of novel coronavirus (2019-nCoV). 2005.

12. Woodward A. It's Estimated 1 in 4 Coronavirus Carriers Could Be Asymptomatic. Here's What We Know. Science alert. Published online 3 April 2020. Available at: https://www.sciencealert.com/here-s-what-we-know-sofar-about-those-who-can-pass-corona-without-symptoms (Accessed: 19 April 2020).

13. Mandavilli A. Infected but Feeling Fine: The Unwitting Coronavirus Spreaders. The New York Times. Published 31 March 2020. Available at: https://www.nytimes.com/2020/ 03/31/health/coronavirus-asymptomatictransmission.html

14. Foster P, Foster L, Renfrew $C$ et al. Phylogenic network analysis of SARS-CoV-2 genomes. PNAS first published April 8, 2020. https://doi.org/10.1073/pnas.2004999117 PMid:32269081 PMCid:PMC7196762

15. Wells C, Sah P, Moghadas S, et al. Impact of international travel and border control measures on the global spread of the novel 2019 coronavirus outbreak. PNAS March 31, 2020. https://doi.org/10.1073/pnas.2002616117 PMid:32170017 PMCid:PMC7132249

16. Cao Y, Li L, Feng Z, et al. Comparative genetic analysis of the novel coronavirus (2019-nCoV/SARS-CoV-2) receptorACE2 in different populations. Correspondence. Cell Discovery. 2020. https://doi.org/10.1038/s41421-020-0147-1 PMid: 32133153 PMCid:PMC7040011

17. Saab Y, Gard P, Overall A. The geographic distribution of the ACEII genotype: a novel finding. Gent. Res. Camb, 2007;89:259-67. https://doi.org/10.1017/S0016672307009 019 PMid:18208631 